\title{
Phytochemical analysis and in vitro anthelmintic activity of Imperata cylindrica underground parts
}

\author{
Pawi Bawitlung Lalthanpuii(D) and Kholhring Lalchhandama* (B)
}

\begin{abstract}
Background: Imperata cylindrica is considered as an agricultural weed, but it is a valuable plant in the traditional medicines of Southeast Asia. In the Mizo traditional medicine of India and Myanmar, the rhizomes and roots are used as a remedy for bacterial, fungal and intestinal helminth infections.

Methods: An extract of the whole underground parts was prepared in Soxhlet apparatus using chloroform as a solvent. After concentrating in a vacuum rotary evaporator, the extract was analysed using gas chromatographymass spectrometry. Anthelmintic activity was tested in vitro against the tapeworm Raillietina tetragona and the roundworm Ascaridia galli. Scanning electron microscopy was used to examine the structural changes on the helminths after treatment with the plant extract.

Results: Twenty-two compounds were identified from the plant extract out of which fatty acids were the predominant compounds. Palmitic acid was the most abundant. Bioactive phytosterols such as campesterol and stigmasterol were also detected. The plant extract was significantly effective on both the helminths and showed dose-dependent anthelmintic activity as that of albendazole. The tapeworm treated with the plant extract showed deformities on the suckers, clumping of the spines, tegumental folds and erosion of microtriches. Extensive damage was also seen on the roundworm including cuticular shrinkage, collapse of the lips, and formation of warty surface throughout the body.

Conclusion: I. cylindrica extract effectively killed and caused detrimental effects on parasitic tapeworm and roundworm. The study therefore validates the traditional usage among the Mizo people, and guarantees further investigation on the exact compound(s) and mechanism of action.
\end{abstract}

Keywords: Anthelmintic, Medicinal plant, Roundworm, Scanning electron microscopy, Tapeworm

\section{Background}

Helminthiasis is one of the most persistent scourges of the health and welfare of humans, livestock animals and wildlife. It remains the major factor of human debility, poverty, cognitive weakness and sometimes death [1], as well as of huge economic losses in animal industry [2]. According to the current estimate, roundworms alone

\footnotetext{
* Correspondence: chhandama@pucollege.edu.in

Department of Life Sciences, Pachhunga University College, Aizawl, Mizoram 796001, India
}

\section{$\triangle B M C$}

C C The Author(s). 2020 Open Access This article is licensed under a Creative Commons Attribution 4.0 International License, which permits use, sharing, adaptation, distribution and reproduction in any medium or format, as long as you give appropriate credit to the original author(s) and the source, provide a link to the Creative Commons licence, and indicate if changes were made. The images or other third party material in this article are included in the article's Creative Commons licence, unless indicated otherwise in a credit line to the material. If material is not included in the article's Creative Commons licence and your intended use is not permitted by statutory regulation or exceeds the permitted use, you will need to obtain permission directly from the copyright holder. To view a copy of this licence, visit http://creativecommons.org/licenses/by/4.0/ The Creative Commons Public Domain Dedication waiver (http://creativecommons.org/publicdomain/zero/1.0/) applies to the data made available in this article, unless otherwise stated in a credit line to the data. somes (flukes) account for 220 million cases [4] Tapeworms are the least prevalent among them but are responsible for the worst outcomes such as neurocysticercosis, which cause permanent brain damage and premature fatality. Helminthiasis also intensifies other infections such as those of Plasmodium falciparum, human immunodeficiency virus (HIV), and Mycobacterium tuberculosis [5]. No new drugs have been developed for several decades [6], while anthelmintic 
resistance is evolving at an accelerated pace in the most important helminth parasites of livestock animals [7] and humans [8].

The tapeworm Raillietina tetragona Molin, 1858, and the roundworm Ascaridia galli Schrank, 1788, are the most prevalent and thereby the most important parasites of birds in different parts of the world [9-11]. They cause detrimental health conditions and pathological symptoms including anaemia, droopiness, emaciation and diarrhoea [12]. The consequences such as loss of appetite, weight loss, reduced egg production and death lead to economic losses in poultry farming [13]. In spite of their huge influences in avian health and poultry production, there are no prescription anthelmintic drugs.

Medicinal plants are as a source of many important pharmaceutical drugs, but they have not yet produced a single anthelmintic drug. An interesting plant is Imperata cylindrica (L.) Raeusch. (family - Poaceae), the underground parts (rhizomes and roots) of which are used in Mizo traditional medicine as a treatment for intestinal helminthiasis, fungal infections, blood urine (haematuria), blood vomit (haematemesis), and nosebleed (epistaxis) [14]. Although the plant is regarded as a noxious weed [15], it is recognised in Southeast Asian cultures as an antibacterial, anticoagulant (styptic), antipyretic (febrifuge), water pill (diuretic), skin smoothening (emollient), salivating (sialagogue), and blood soothing (tonic) agent [16]. Its effects on circulatory system such as in vasodilation and blood flow have been reported $[17,18]$.

Practically no attention has been given to this plant in terms of chemical analysis and biological activities against parasites. It is therefore challenging to study its effect on intestinal parasites.

A remarkable fact is that while most anthelmintic drugs are helminth specific, i.e. they are effective only against a particular group of helminths, I. cylindrica is acclaimed to be equally effective against both tapeworms and roundworms [14]. Identification of important compounds present in the plant extract and anthelmintic tests using both tapeworm and roundworm will be useful for further investigations on the pharmacology of this plant.

\section{Methods}

\section{Plant material and extraction}

I. cylindrica was collected from Ngopa, Mizoram, India, which is located between $23.8861^{\circ}$ latitude north and $93.2119^{\circ}$ longitude east. The plant specimen with voucher number PUC-I-2018-01 was authenticated at the Botanical Survey of India (BSI), Shillong, Meghalaya, India. The aerial parts were discarded and the underground parts including rhizomes and roots were dried in shade at $21-25^{\circ} \mathrm{C}$. The dried parts were ground to fine powder using electric blender.

The plant extracts were prepared in a 5-1 capacity Soxhlet apparatus using three solvents such as methanol (polar solvent), chloroform (medium polar solvent) and hexane (non-polar solvent). The extracts were concentrated by removing and recovering the solvents in a vacuum rotary evaporator (Buchi Rotavapor ${ }^{\circ}$ R-215) [14]. The final extracts were obtained as semisolid precipitates and were stored at $4{ }^{\circ} \mathrm{C}$ until use. The chloroform extract was found to contain the most abundant compounds and showed the highest biological activity, and thus was used for complete chemical analysis and anthelmintic assay.

\section{Chemicals and drug}

All chemicals were standard analytical grades procured from HiMedia Laboratories Private Limited, Mumbai, India. Acetonitrile for gas chromatography and tetramethylsilane for electron microscopy were products of Merck Life Science Private Limited, Mumbai, India. A standard anthelmintic, albendazole $\left(\right.$ ZENTEL $\left.^{\circ}\right)$ was a product of GlaxoSmithKline Pharmaceuticals Ltd, Mumbai, India.

\section{Chemical analysis}

The chemical constituent of the plant extract was analysed in a single quadrupole gas chromatography-mass spectrometry system (Thermo Scientific TRACE ${ }^{\mathrm{m}} 1300$ $\left.\mathrm{ISQ}^{\mathrm{m}} \mathrm{LT}\right)$. Acetonitrile was used to dissolve the extract. GC elution was done in a non-polar column TR-5MS (260F142P) having a dimension of $30 \mathrm{~m} \times 0.25 \mathrm{~mm} \times$ $0.25 \mu \mathrm{m}$ and film thickness of $0.25 \mu \mathrm{m}$. Temperature of the injector port was set at $250^{\circ} \mathrm{C}$. The oven temperature was initially set at $70^{\circ} \mathrm{C}$ for $2 \mathrm{~min}$ and incrementally increased at $10^{\circ} \mathrm{C}$ up to $250^{\circ} \mathrm{C}$. Helium was used a carrier gas and passed at a constant flow rate of $1 \mathrm{ml} / \mathrm{min}$. One microliter of the sample was injected in a splitting ratio of 1:50. The ionisation electron energy of the mass spectrometer was set at $70 \mathrm{eV}$. Ion source and transfer line temperature were set at $250{ }^{\circ} \mathrm{C}$. The running duration was $55 \mathrm{~min}$. The final chromatogram was generated with Thermo Scientific ${ }^{\mathrm{mi}}$ Xcalibur $^{\mathrm{Tm}}$ software. Compounds were identified based on their chemical formula, retention time, and molecular weight from the libraries of Wiley Registry ${ }^{\mathrm{rm}}$ and National Institute of Standards and Technology (NIST) database.

\section{Anthelmintic test}

Anthelmintic activity was studied in vitro on the survival of tapeworm $R$. tetragona, and the roundworm A. galli [19]. The helminth parasites were recovered from the intestines of freshly sacrificed local chicken, Gallus Gallus domesticus Linnaeus, 1758. Use of chicken was 
permitted by the Institutional Ethics Committee of Pachhunga University College (PUC-IEC-2016-Z2 of 10/ 08/2016). The worms were collected and washed in Petri dishes containing $0.9 \%$ neutral phosphate-buffered saline (PBS) maintained at $37 \pm 1{ }^{\circ} \mathrm{C}$ in a glass-panelled microbiological incubator. I. cylindrica chloroform extract was prepared in exponential concentrations of 1.25, 2.5, 5, 10 and $20 \mathrm{mg} / \mathrm{ml}$ by dissolving in PBS supplemented with $1 \%$ dimethylsulfoxide (DMSO). A broad-spectrum anthelmintic, albendazole (with a standard dosage of 20 $\mathrm{mg} / \mathrm{ml}$ ) was prepared similarly as a positive control. Negative control consisted of worms kept in Petri dishes containing only PBS with $1 \%$ DMSO. All the media were maintained at $37 \pm 1{ }^{\circ} \mathrm{C}$. A set of five worms were introduced into each media, and each test was performed in triplicates.

Survival was defined as a total loss of motor activity after stimulation by dipping the parasites in lukewarm PBS $\left(45^{\circ} \mathrm{C}\right)$. Data were generated as means \pm standard deviation and presented in normalised values against the control. Student's $t$-test was used to determine the statistical significance and the level of significance was considered when $p$ value was less than 0.05 .

\section{Scanning electron microscopy}

Helminths in control experiment and those treated with $20 \mathrm{mg} / \mathrm{ml}$ of the plant extract were processed for scanning electron microscopy to compare the structural appearances based on a standardized method for helminths [20]. They were first fixed in $10 \%$ formaldehyde (buffered with $0.1 \mathrm{M}$ sodium cacodylate) at $4{ }^{\circ} \mathrm{C}$ for $4 \mathrm{~h}$. Then a secondary fixation was done with $1 \%$ osmium tetroxide at $4{ }^{\circ} \mathrm{C}$ for $1 \mathrm{~h}$. They were dehydrated through a series of acetone in increasing concentrations. After treating with tetramethylsilane for $15 \mathrm{~min}$ they were dried in an air-drying chamber at $25^{\circ} \mathrm{C}$. They were mounted on metal stubs and sputter coated with gold in
JFC-1100 (JEOL Ltd., Tokyo, Japan) ion-sputtering chamber. Finally, they were observed under a JSM-6360 scanning electron microscope (JEOL Ltd., Tokyo, Japan) at an electron accelerating voltage of $20 \mathrm{kV}$.

\section{Results}

Chemical analysis

GC-MS chromatogram of the chloroform extract of $I$. cylindrica underground parts is shown in Fig. 1, and the corresponding list of compounds identified from it is given in Table 1. Twenty-two compounds were identified. Fatty acids are the major constituents comprise $64 \%$ of the total volatile components. Palmitic acid (hexadecanoic acid) is by far the most abundant with an abundance of $15.5 \%$, and its methyl ester is also detected (9.5\%). Other major compounds included (Z)-18-octadec-9-enolide (11.8\%), 2,4-di-tert-butylphenol (11\%), octadecanoic acid (10.9\%), and 9-hexadecen-1-ol (907\%). Phytosterols such as campesterol (1.4\%) and stigmasterol (1.4\%) were also found in moderate amounts.

\section{Anthelmintic activity}

The in vitro anthelmintic activity of the chloroform extract of $I$. cylindrica against the tapeworm, $R$. tetragona is presented in Table 2. Tapeworms in the control media survived for $74.19 \mathrm{~h}$. Normalised survival values indicate significant concentration-dependent effects at all concentrations tested. Albendazole was more effective and killed all the worms in $24.07 \pm 1.62 \mathrm{~h}$ and $4.70 \pm 0.84 \mathrm{~h}$ at the lowest $(1.25 \mathrm{mg} / \mathrm{ml})$ and highest concentrations $(20$ $\mathrm{mg} / \mathrm{ml}$ ), respectively. I. cylindrica chloroform extract took $91.81 \pm 2.36 \mathrm{~h}$ and $36.53 \pm 2.66 \mathrm{~h}$ at corresponding concentrations.

Anthelmintic activity of the chloroform extract of $I$. cylindrica on A. galli is shown in Table 3. Roundworms were more resilient that tapeworms and survived up to $216.29 \mathrm{~h}$ in control media. Albendazole was again highly

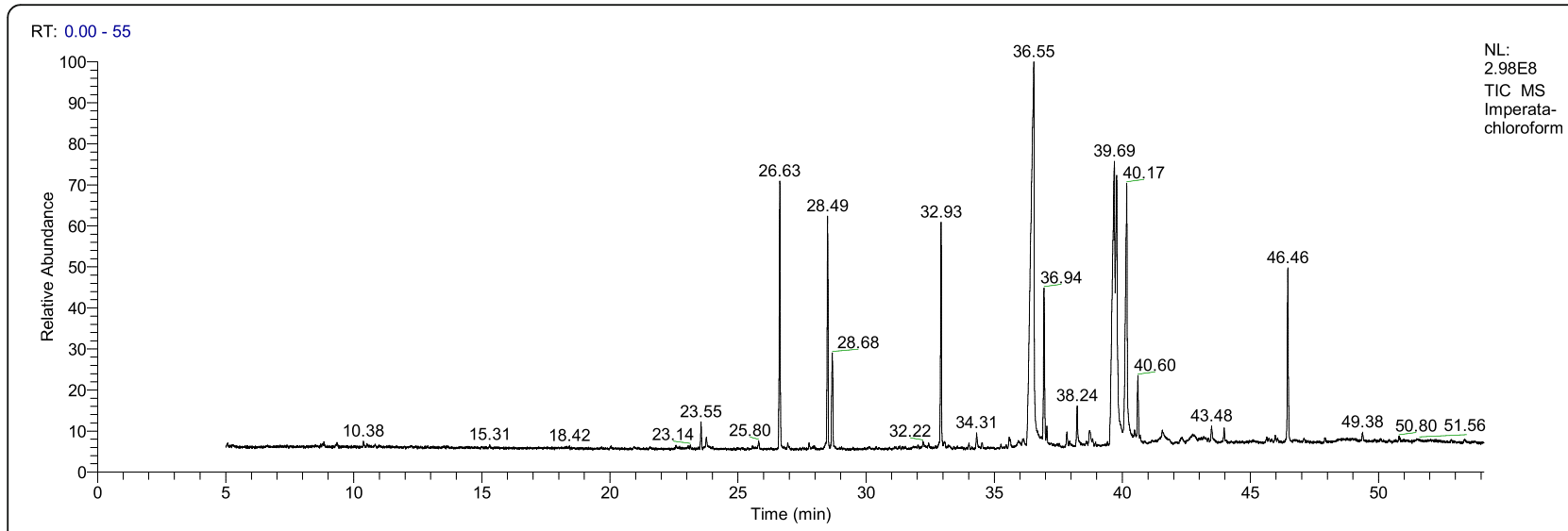

Fig. 1 GC-MS chromatogram of the chloroform extract of I. cylindrica underground parts. Total retention time was 55 min 
Table 1 List of compounds identified from chloroform extract of I. cylindrica underground parts using GC-MS

\begin{tabular}{|c|c|c|c|c|c|}
\hline SI. & $\begin{array}{l}\text { Retention time } \\
(\mathrm{min})\end{array}$ & Compound & Formula & $\begin{array}{l}\text { Molecular weight } \\
(\mathrm{Da})\end{array}$ & $\begin{array}{l}\text { Abundance } \\
(\%)\end{array}$ \\
\hline 1. & 10.38 & $\begin{array}{l}\text { 3,5-Bis (1,1-dimethylethyl)-4-hydroxy benzenepropanoic acid, } \\
\text { octadecyl ester }\end{array}$ & $\mathrm{C}_{36} \mathrm{H}_{62} \mathrm{O}_{3}$ & 530 & 1.1 \\
\hline 2. & 15.31 & 13-Heptadecyn-1-ol & $\mathrm{C}_{17} \mathrm{H}_{32} \mathrm{O}$ & 252 & 1.1 \\
\hline 3. & 18.42 & 6-Methylenebicyclo [3.2.0] hept-3-en-2-one & $\mathrm{C}_{8} \mathrm{H}_{8} \mathrm{O}$ & 120 & 1.0 \\
\hline 4. & 23.14 & 2-Methoxy-4-vinylphenol & $\mathrm{C}_{9} \mathrm{H}_{10} \mathrm{O}_{2}$ & 150 & 1.0 \\
\hline 5. & 23.55 & 3-(Chloroacetoxy)-4-methoxy benzaldehyde & $\mathrm{C}_{10} \mathrm{H}_{9} \mathrm{ClO}_{2}$ & 228 & 1.9 \\
\hline 6. & 25.80 & 2-Octyl cyclopropanetetradecanoic acid, methyl ester & $\mathrm{C}_{26} \mathrm{H}_{50} \mathrm{O}_{2}$ & 394 & 1.2 \\
\hline 7. & 26.63 & 2,4-Di-tert-butylphenol & $\mathrm{C}_{14} \mathrm{H}_{22} \mathrm{O}$ & 206 & 11.0 \\
\hline 8. & 28.49 & 9-Hexadecen-1-ol & $\mathrm{C}_{16} \mathrm{H}_{32} \mathrm{O}$ & 240 & 9.7 \\
\hline 9. & 28.68 & 2,2,4-Trimethyl-1,3-pentanediol diisobutyrate & $\mathrm{C}_{16} \mathrm{H}_{30} \mathrm{O}_{4}$ & 286 & 4.2 \\
\hline 10. & 32.22 & (E)-4-(3-Hydroxyprop-1-en-1-yl)-2-methoxyphenol & $\mathrm{C}_{10} \mathrm{H}_{12} \mathrm{O}_{3}$ & 180 & 1.2 \\
\hline 11. & 32.93 & Palmitic acid, methyl ester & $\mathrm{C}_{17} \mathrm{H}_{34} \mathrm{O}_{2}$ & 270 & 9.5 \\
\hline 12. & 36.55 & Palmitic acid (hexadecanoic acid) & $\mathrm{C}_{16} \mathrm{H}_{32} \mathrm{O}_{2}$ & 256 & 15.5 \\
\hline 13. & 36.94 & $\begin{array}{l}\text { L-Methionyl-D-glutaminyl-D-methionyl-L-asparaginyl- } \\
\text { L-lysyl-L-valyl-L-leucyl-D-a-aspartyl-L-serine }\end{array}$ & $\mathrm{C}_{43} \mathrm{H}_{76} \mathrm{~N}_{12} \mathrm{O}_{15} \mathrm{~S}_{21}$ & 1064 & 7.0 \\
\hline 14. & 38.24 & Methyl 9-cis, 11 trans-octadecadienoate & $\mathrm{C}_{19} \mathrm{H}_{34} \mathrm{O}_{2}$ & 294 & 2.5 \\
\hline 15. & 39.69 & (Z)-18-Octadec-9-enolide & $\mathrm{C}_{18} \mathrm{H}_{32} \mathrm{O}_{2}$ & 280 & 11.8 \\
\hline 16. & 40.17 & Octadecanoic acid & $\mathrm{C}_{18} \mathrm{H}_{36} \mathrm{O}_{2}$ & 284 & 10.9 \\
\hline 17. & 40.60 & Heptacos-1-ene & $\mathrm{C}_{27} \mathrm{H}_{54}$ & 378 & 3.6 \\
\hline 18. & 43.48 & Octadecanoic acid, ethyl ester & $\mathrm{C}_{25} \mathrm{H}_{42} \mathrm{O}_{2}$ & 374 & 1.7 \\
\hline 19. & 46.46 & Diisooctyl phthalate & $\mathrm{C}_{24} \mathrm{H}_{38} \mathrm{O}_{4}$ & 390 & 7.7 \\
\hline 20. & 49.38 & 17a,21ß-28,30-Bisnorhopane & $\mathrm{C}_{28} \mathrm{H}_{48}$ & 384 & 1.5 \\
\hline 21. & 50.80 & Campesterol & $\mathrm{C}_{28} \mathrm{H}_{48} \mathrm{O}$ & 400 & 1.4 \\
\hline 22. & 51.56 & Stigmasterol & $\mathrm{C}_{29} \mathrm{H}_{48} \mathrm{O}$ & 412 & 1.4 \\
\hline
\end{tabular}

effective on the roundworm. It took $43.54 \pm 0.97 \mathrm{~h}$ and $1.81 \pm 0.38 \mathrm{~h}$ to kill the worms at the lowest and highest concentrations, respectively. While it took $95.67 \pm 1.77 \mathrm{~h}$ and $81.56 \pm 1.71 \mathrm{~h}$ for I. cylindrica chloroform extract to kill all the worms at corresponding concentrations.

\section{Scanning electron microscopy}

Scanning electron microscopy of an untreated $R$. tetragona is shown in Fig. 2. The tapeworm has an anterior bulb-like scolex which bears the attachment organs called suckers (Fig. 2a). Each sucker is oval shaped and

Table 2 Anthelmintic activity of the chloroform extract of $I$. cylindrica on $R$. tetragona

\begin{tabular}{|c|c|c|c|c|}
\hline Treatment & Dose $(\mathrm{mg} / \mathrm{ml})$ & Normalised survival time (hour) in mean \pm SD & $t$ value & $t$ critical value \\
\hline Control & 0 & $100.00 \pm 2.00$ & NA & NA \\
\hline \multirow[t]{5}{*}{ Albendazole } & 1.25 & $024.07 \pm 1.62^{*}$ & 114.35 & 2.05 \\
\hline & 2.5 & $020.51 \pm 1.21^{*}$ & 131.56 & 2.07 \\
\hline & 5 & $016.56 \pm 0.99^{*}$ & 144.85 & 2.08 \\
\hline & 10 & $012.22 \pm 1.05^{*}$ & 150.56 & 2.08 \\
\hline & 20 & $004.70 \pm 0.84^{*}$ & 170.05 & 2.09 \\
\hline \multirow[t]{5}{*}{ 1. cylindrica extract } & 1.25 & $091.81 \pm 2.36^{*}$ & 010.25 & 2.05 \\
\hline & 2.5 & $089.40 \pm 1.71^{*}$ & 015.60 & 2.05 \\
\hline & 5 & $082.48 \pm 3.02^{*}$ & 018.74 & 2.06 \\
\hline & 10 & $064.73 \pm 2.55^{*}$ & 042.15 & 2.06 \\
\hline & 20 & $036.53 \pm 2.67^{*}$ & 073.85 & 2.06 \\
\hline
\end{tabular}

NA Not applicable; $n=15 ; t$ value is the calculated difference represented in units of standard error, the higher the value, the greater the evidence against the null hypothesis; $t$ critical value denotes the value that must be exceeded to get a significant level

*Significantly different at $p<0.05$ against control 
Table 3 Anthelmintic activity of the chloroform extract of I. cylindrica on A. galli

\begin{tabular}{|c|c|c|c|c|}
\hline Treatment & Dose $(\mathrm{mg} / \mathrm{ml})$ & $\begin{array}{l}\text { Normalised survival time } \\
\text { (hour) in mean } \pm \text { SD }\end{array}$ & $t$ value & $t$ critical value \\
\hline Control & 0 & $100.00 \pm 0.97$ & NA & NA \\
\hline \multirow[t]{5}{*}{ Albendazole } & 1.25 & $043.54 \pm 0.97^{*}$ & 159.16 & 2.05 \\
\hline & 2.5 & $036.74 \pm 0.83^{*}$ & 192.16 & 2.05 \\
\hline & 5 & $026.15 \pm 0.72^{*}$ & 236.69 & 2.06 \\
\hline & 10 & $008.12 \pm 0.92^{*}$ & 266.53 & 2.05 \\
\hline & 20 & $001.81 \pm 0.38^{*}$ & 365.24 & 2.10 \\
\hline \multirow[t]{5}{*}{ 1. cylindrica extract } & 1.25 & $095.67 \pm 1.77^{*}$ & 008.30 & 2.07 \\
\hline & 2.5 & $090.13 \pm 1.63^{*}$ & 020.13 & 2.07 \\
\hline & 5 & $084.46 \pm 1.10^{*}$ & 040.99 & 2.05 \\
\hline & 10 & $082.94 \pm 2.11^{*}$ & 028.42 & 2.09 \\
\hline & 20 & $081.56 \pm 1.71^{*}$ & 036.43 & 2.07 \\
\hline
\end{tabular}

NA Not applicable; $n=15 ; t$ value is the calculated difference represented in units of standard error, the higher the value, the greater the evidence against the null hypothesis; $t$ critical value denotes the value that must be exceeded to get a significant level

*Significantly different at $p<0.05$ against control

is lined with rows of pointed projections called the spines (Fig. 2b). The main body consists of a series of body segments or proglottids. The proglottids appear smooth and silky as the tegument (body surface) is made up of microscopic hairs called microtriches (Fig. 2c).

R. tetragona treated with $20 \mathrm{mg} / \mathrm{ml}$ of the chloroform extract of I. cylindrica revealed extensive changes on the tegument throughout the body. The scolex as shown in Fig. 3a indicates tegumental erosion and distortion of the suckers. Irregular masses on the general tegument and around the suckers are visible. In each sucker, the spines clumped and a central pit is formed which indicates tegumental erosion (Fig. 3b). Folding of the tegument and degeneration of microtriches are evident on all the proglottids (Fig. 3c).

Scanning electron microscopy of an untreated A. galli is presented in Fig. 4. The terminal end of the anterior part of the body consists of three blob-like structures called the lips. The lips surround the mouth. Sensory organs called papillae are seen as protrusions on the lips (Fig. 4a). The general body surface, called the cuticle, is rigid and smooth. There are straight and parallel transverse rings called annulations throughout the body (Fig. 4b). The tail end bears anal opening or cloaca, precloacal sucker and several sensory protrusions called amphids (Fig. 4c).

The anthelmintic effects are more pronounced on $A$. galli treated with $20 \mathrm{mg} / \mathrm{ml}$ of the chloroform extract of I. cylindrica. The deleterious effects are particularly pronounced on the head region as shown in Fig. 5a. Three lips fully collapsed and the surrounding cuticle is massively shrunken. The main body is extensively shrunk with the formation of irregular warts all over the cuticle. The annulations are completely distorted (Fig. 5b). The deformity extends to the tail region as shown in Fig. 5c.
Cuticular shrinkage extends to the tip of the tail. The amphids are degenerated and there is formation of scar in the precloacal sucker.

\section{Discussion}

I. cylindrica has been an interesting plant in traditional Chinese medicine. It is known to be rich in phenols and triterpenes $[21,22]$. It contains several unique compounds including graminone B [18], impecylone, impecyloside, deacetylimpecyloside, seguinoside [23], tabanone [24], and different chromones [25]. In addition, four novel chromones isolated from the rhizome exhibited neuroprotective activity in vitro [17]. Imperanine and cylindol A [1] and B isolated from the roots were shown to have anti-inflammatory activity [26, 27]. A novel chromone, isoegenin from the rhizome also showed anti-inflammatory activity [28].

In the present study, the rhizomes and roots appear to contain a number of important bioactive compounds. For instance, palmitic acid has antibacterial activity against different types of pathogenic bacteria $[29,30]$. It also shows selective cytotoxicity upon human leukemic cells [31]. 2-Methoxy-4-vinylphenol isolated from pine (Pinus species) exhibits anticancer activity in vitro against different cancer cell lines [32]. It was also shown to exhibit immunomodulatory activity by enhancing antiinflammatory response suppression of NF- $\mathrm{kB}$ and MAPK activation, and acetylation of histone H3 [33]. 2, 4-Di-tert-butylphenol from Persea americana is a potent antimicrobial compound against pathogenic microbes such as Aspergillus sp. and Phytophthora cinnamomi [34]. 6-Methylenebicyclo [3.2.0] hept-3-en-2-one is reported from Allium tuberosum and was shown to play an important role in immunity against parasitic infection such as root-knot nematode, Meloidogyne species [35]. 

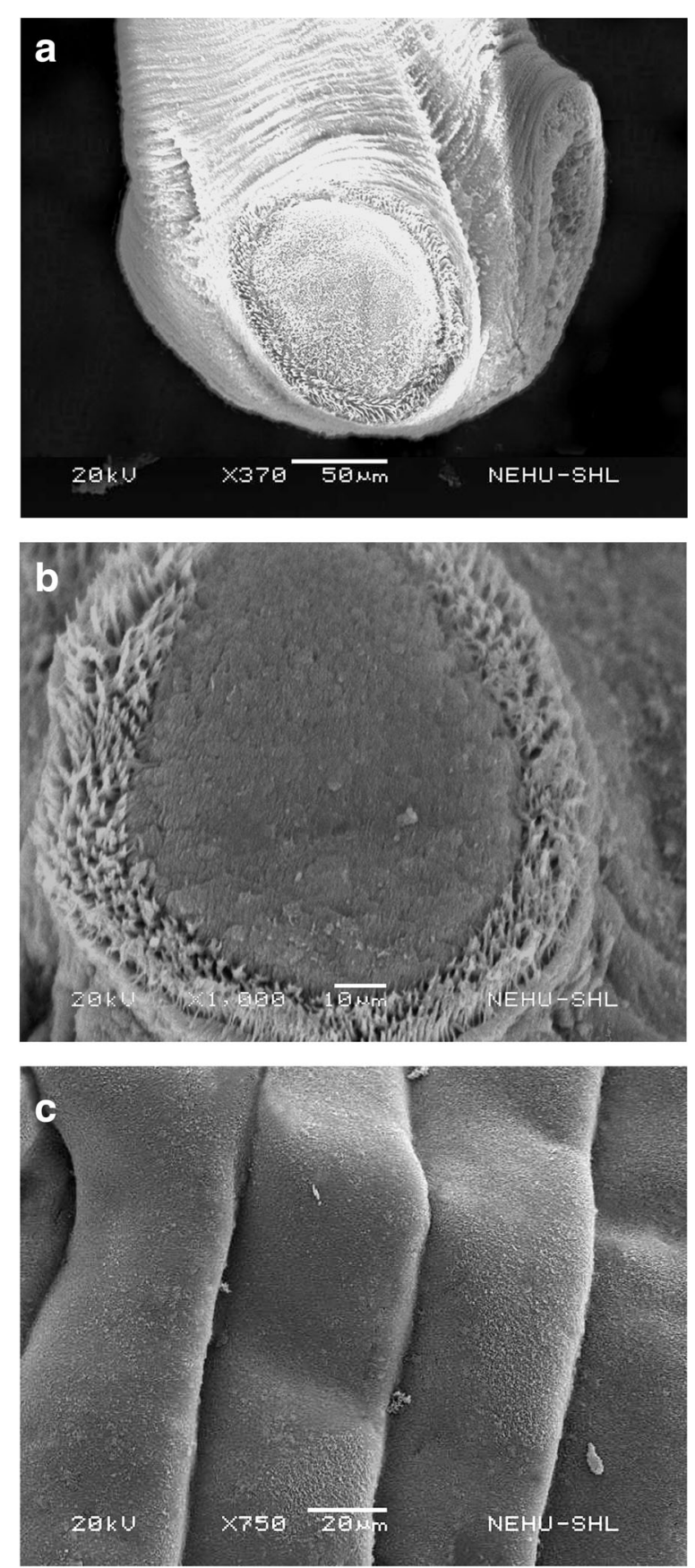

Fig. 2 Scanning electron micrographs of an untreated R. tetragona. a The anterior end showing a bulbuous terminal called the scolex which bears prominent suckers (arrows). $\times 370$. Scale bar $=50 \mu \mathrm{m}$. $\mathbf{b}$ A single sucker which is oval shaped and lined with several rows of hooks (arrows). $\times 1000$. Scale bar $=10 \mu \mathrm{m}$. c The body segments called proglottids with smooth tegument due to fine microscopic hairs, the microtriches. $\times 750$. Scale bar $=20 \mu \mathrm{m}$

Phytosterols are known for their blood-lipid lowering and anticancer activities. Campesterol inhibits fibroblast growth factor and tube formation of human umbilical vein endothelial cells, thereby indicating its role in the
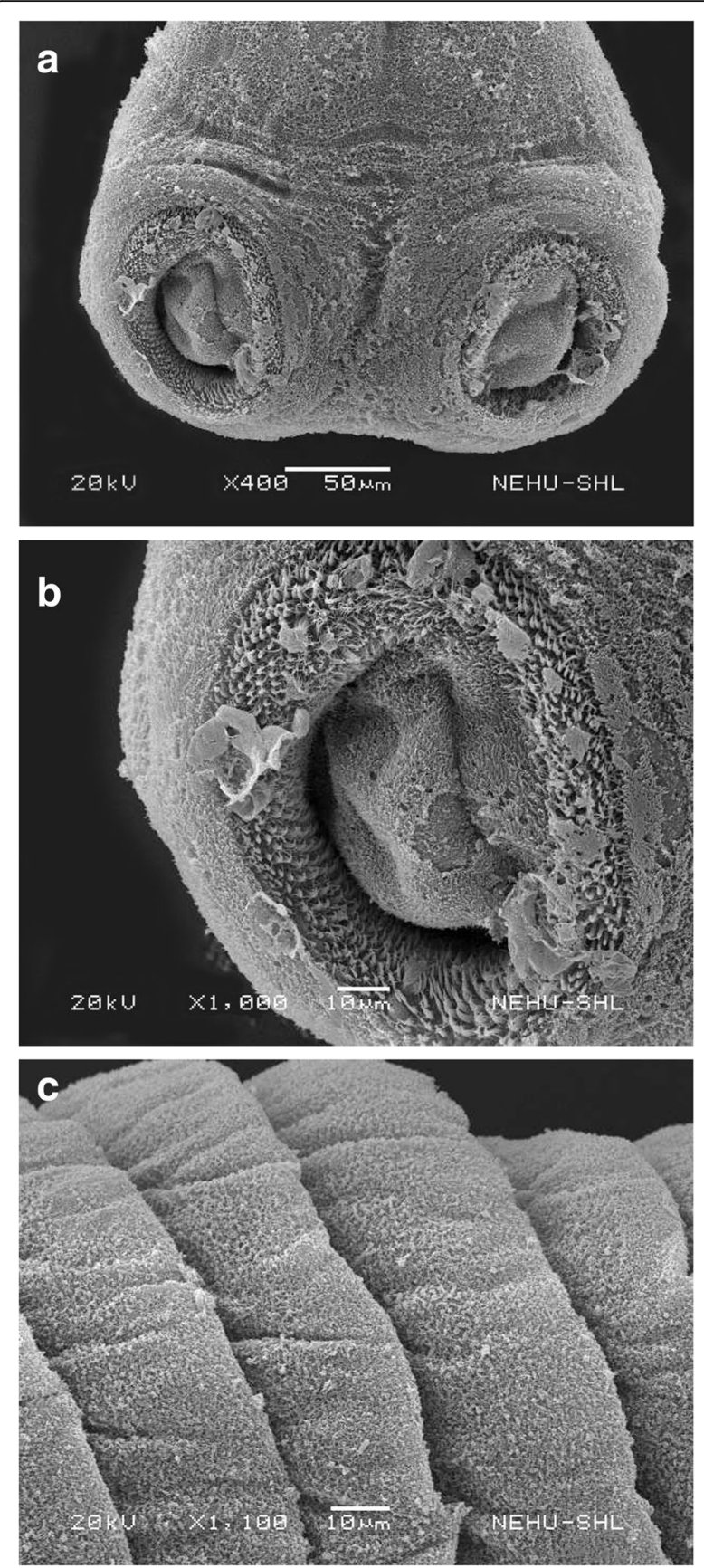

Fig. 3 Scanning electron micrographs of R. tetragona treated with I. cylindrica extract. a The scolex indicating damage of tegumental (upper arrow) and suckers (lower arrow). $\times 400$. Scale bar $=50 \mu \mathrm{m}$. b A sucker indicates clumping (upper arrow) and erosion at the central pit (lower arrow) $\times 1000$. Scale bar $=10 \mu \mathrm{m}$. c The proglottids are wrinkled (upper arrow) and the tegument appears fuzzy due to degeneration of microtriches (lower arrow). $\times 1100$. Scale bar $=10 \mu \mathrm{m}$

prevention of blood cancers [36]. Increased $\beta$-sitosterol and campesterol in the blood circulation inhibits proliferation of cancer cells in mice [37]. Campesterol, $\beta$ sitosterol, and stigmasterol are reported to decrease the 

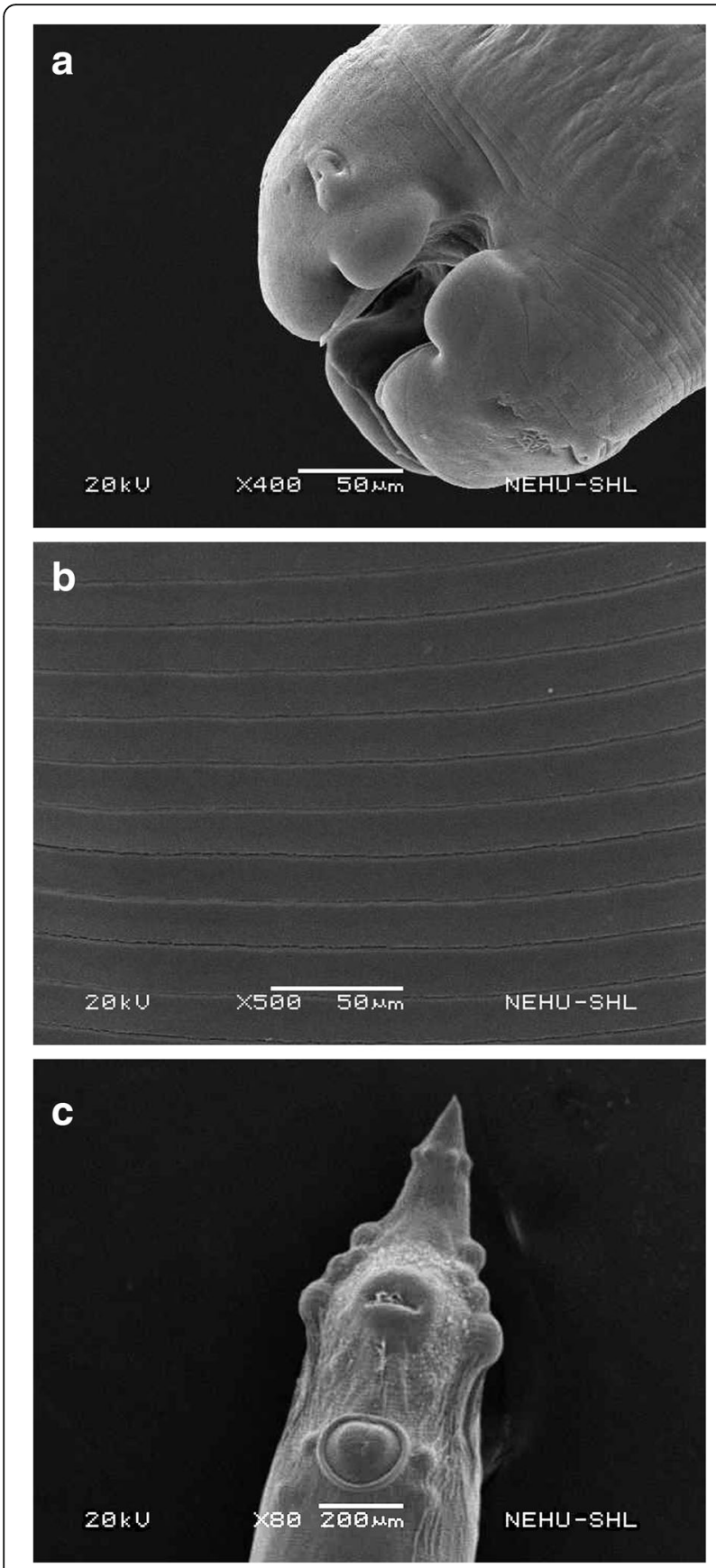

Fig. 4 Scanning electron micrographs of an untreated A. galli. a The anterior part bears three terminal blob-like structures called the lips, which have small protrusion called papilla (upper arrow) and surround the mouth (lower arrow). $\times 400$. Scale bar $=50 \mu \mathrm{m}$. b The body surface called the cuticle in the middle of the body is smooth and lined with parallel rows of transverse striations called

annulations (arrows). $\times 500$. Scale bar $=50 \mu \mathrm{m}$. c The posterior end is the tail which bears anal opening or cloaca (top arrow), a precloacal sucker (middle arrow) and sensory protrusions called phasmids (bottom arrow). $\times 80$. Scale bar $=200 \mu \mathrm{m}$
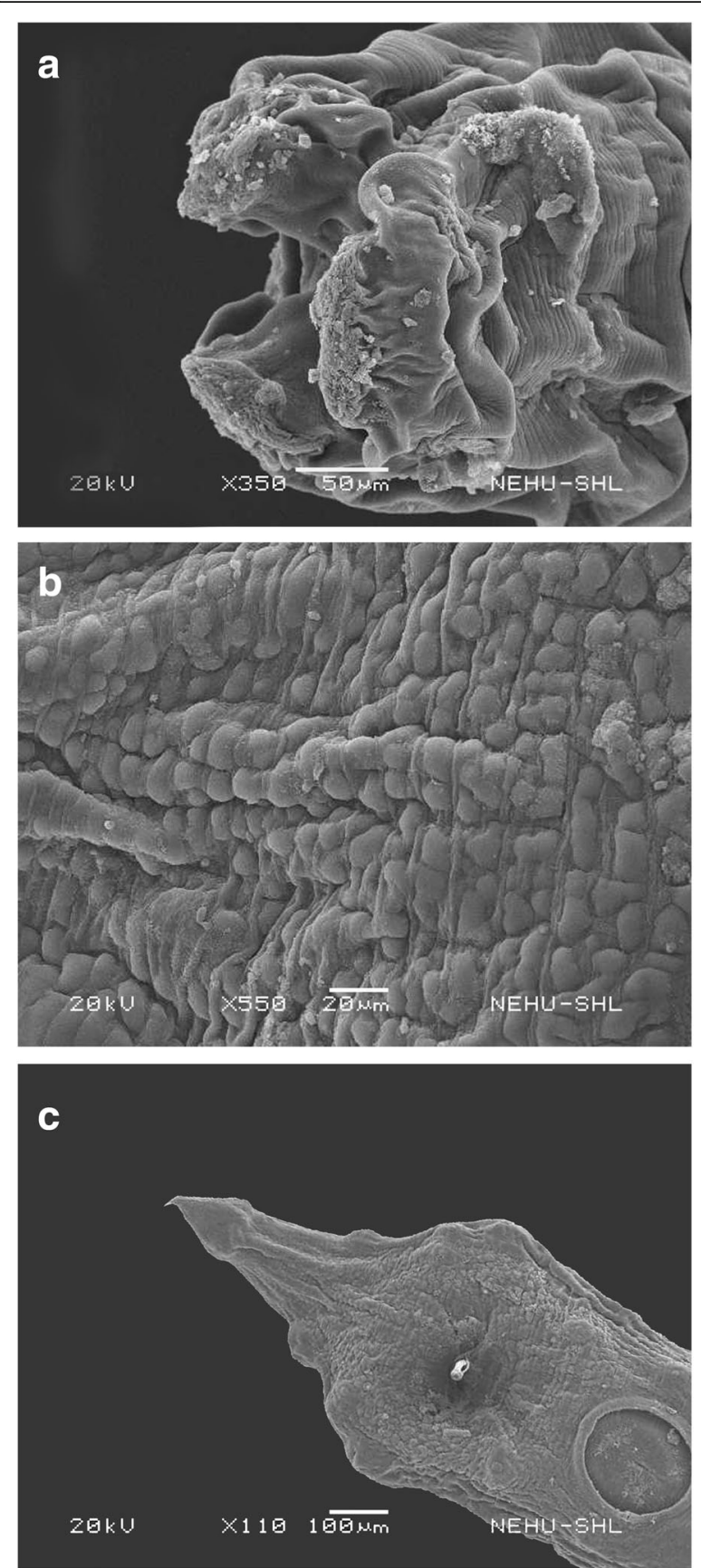

Fig. 5 Scanning electron micrographs of A. galli treated with I. cylindrica extract. a The lips are shrunk and contracted (upper arrow) and the surrounding cuticle is also shrivelled (lower arrow). $\times 350$. Scale bar $=50 \mu \mathrm{m}$. $\mathbf{b}$ Extensive shrinkage of the main body with formation of warts on the cuticle (arrows). $\times 550$. Scale bar $=20 \mu \mathrm{m}$. c Shrinkage extends to the tail (top arrow), phasmids are distorted (middle arrow) and there is scar formation in the precloacal sucker (bottom arrow). $\times 110$. Scale bar $=100 \mu \mathrm{m}$

risk of gastric cancer [38] and lung cancer [39]. But campesterol and stigmasterol have no beneficial effect in colon cancer [40]. These compounds are therefore likely cancer-specific and are useful for people with 
cardiovascular diseases and cancers [41]. Stigmasterol is further attributed to prevention of osteoarthritis as it inhibits proteins of chondrocytes [42]. It also exhibits hypoglycaemic activity by reducing serum thyroid hormones, triiodothyronine $\left(\mathrm{T}_{3}\right)$ and thyroxin $\left(\mathrm{T}_{4}\right)$, as well the activity of hepatic glucose-6-phophatase [43].

Substantiating the therapeutic usage of I. cylindrica as in the Mizo traditional medicine, the findings show that the plant extract does exert an appreciable anthelmintic activity against both tapeworm and roundworm. Damaging effects were seen on the tegument and suckers of the tapeworm $R$. tetragona, and on the cuticle and lips of the roundworm $A$. galli. These distinctive effects are to be expected because tapeworms and roundworms belong to two completely distinct classes (phyla) and have major differences in structural and physiological properties [44, 45]. In tapeworms, absorption of nutrients or drugs is directly through the body surface, the tegument, and this nature makes drugs act faster [46]. But roundworms are covered with a hard cuticle so that nutrients or drugs are absorbed poorly and slowly; thereby delaying the course of drug action [47]. A prolonged activity is therefore expected for plant extracts such as in the present study that would contain only small quantity of the bioactive compound(s). Tegumental shrinkage, disintegration of microtriches and deformity of the suckers as seen in the present study are the major effects of anthelmintic drugs on tapeworms, albeit with varying degree of damages for different drugs $[48,49]$. In roundworms, the signature anthelmintic effects include shrinkage and folding of the cuticle, deflation of the lips and damages on the papillae $[50,51]$. Thus, I. cylindrica extract produced the most notable anthelmintic effects on both tapeworm and roundworm of poultry, and thus has a potential for application in veterinary animals. However, the present in vitro test does not warrant similar efficacy for in vivo condition, therefore, poses the need for in vivo test and identification of the main anthelmintic compound.

\section{Conclusion}

The study revealed that I. cylindrica rhizomes and roots contain important bioactive compounds, which exert anthelmintic activity on both tapeworm and roundworm. GC-MS analysis indicated that the chloroform extract of the underground parts is rich in saturated fatty acids. In concurrence with the usage of the plant in the Mizo traditional medicine as an anthelmintic agent, the plant extract was shown to be effective against $R$. tetragona and A. galli. Tegumental damages on the tapeworm and cuticular distortion on the roundworm revealed by scanning electron microscopy are clear validations of the broad-spectrum anthelmintic activity of the plant. These findings indicate that the plant contains interesting bioactive compound(s) that can serve as lead molecule in anthelmintic development.

\section{Abbreviations}

BSI: Botanical Survey of India; DMSO: Dimethylsulfoxide; GC-MS: Gas chromatography-mass spectrometry; HIV: Human immunodeficiency virus; MAPK: Mitogen-activated protein kinase; NIST: National Institute of Standards and Technology; NF-kB: Tumour necrosis factor kappa B; PBS: Phosphatebuffered saline; SD: Standard deviation; $T_{3}$ : Triiodothyronine; $T_{4}$ : Thyroxin

\section{Acknowledgements}

Scanning electron microscopy was done at the Sophisticated Analytical Instrument Facility (SAIF), North-Eastern Hill University, Shillong, India.

\section{Authors' contributions \\ $\mathrm{KL}$ conceived and designed the study, analysed and interpreted the data, and wrote the first draft of the manuscript. PBL executed the experiments and generated the data. Both authors have read and approved the final manuscript.}

\section{Funding}

Financial support in the form of Extra Mural Research Funding was granted to $\mathrm{KL}$ by the Science and Engineering Research Board (SERB), Government of India (EMR/2016/004053). The funding agency played no role in the concept, execution and outcome of the study.

\section{Availability of data and materials}

The datasets during and/or analysed during the current study are available from the corresponding author on reasonable request.

\section{Ethics approval and consent to participate}

The study was approved by the Institutional Ethics Committee of Pachhunga University College (PUC-IEC-2016-Z2 of 10/08/2016). There are no ethical issues arising from the use of parasites from poultry, and thus, consent is not applicable.

\section{Consent for publication}

Not applicable.

\section{Competing interests}

The authors declare that they have no competing interests.

Received: 19 May 2020 Accepted: 21 October 2020

Published online: 06 November 2020

\section{References}

1. Lo NC, Addiss DG, Hotez PJ, King CH, Stothard JR, Evans DS, et al. A call to strengthen the global strategy against schistosomiasis and soil-transmitted helminthiasis: the time is now. Lancet Infect Dis. 2017;17(2):64-9.

2. Vercruysse J, Charlier J, Van Dijk J, Morgan ER, Geary T, von SamsonHimmelstjerna G, et al. Control of helminth ruminant infections by 2030 . Parasitology. 2018;145(13):1655-64.

3. $[\mathrm{WHO}]$ World Health Organization. Fact sheet - soil-transmitted helminth infections. Geneva: World Health Organization; 2020. https://www.who.int/ news-room/fact-sheets/detail/soil-transmitted-helminth-infections. Accessed 30 Apr 2020.

4. $[\mathrm{WHO}]$ World Health Organization. Fact sheet - schistosomiasis. Geneva: World Health Organization; 2020. https://www.who.int/news-room/factsheets/detail/schistosomiasis. Accessed 30 Apr 2020.

5. Donohue RE, Cross ZK, Michael E. The extent, nature, and pathogenic consequences of helminth polyparasitism in humans: a meta-analysis. PLoS Negl Trop Dis. 2019;13(6):e0007455

6. Liu M, Panda SK, Luyten W. Plant-based natural products for the discovery and development of novel anthelmintics against nematodes. Biomolecules. 2020;10(3):426.

7. Sangster NC, Cowling A, Woodgate RG. Ten events that defined anthelmintic resistance research. Trends Parasitol. 2018;34(7):553-63.

8. Meena R, Mittal A, Samar N, Prajapati M. Albendazole resistant neurocysticercosis - rare unusual case report. Int J Cur Res Rev. 2018; 10(3):7-9.

9. Kaufmann F, Daş G, Sohnrey B, Gauly M. Helminth infections in laying hens kept in organic free range systems in Germany. Livest Sci. 2011; 141(2-3):182-7. 
10. Paul DR, Dey AR, Farhana B, Nurjahan B, Mondal MM. Epidemiology and pathology of intestinal helminthiasis in fowls. Eurasian J Vet Sci. 2012;28(1):31-7.

11. Khaki A, Raza SH, Khan R, Hao L, Hosseini SM, Abdelgayed SS, Kakar MU. Epidemiological and pathological studies on the helminthic parasites in native chickens of Tabriz city, Iran. Genet Mol Res. 2017;16(4): gmr16039824(1-8)

12. Brar RS, Kumar R, Leishangthem GD, Banga HS, Singh ND, Singh H. Ascaridia galli induced ulcerative proventriculitis in a poultry bird. J Parasit Dis. 2016; 40(2):562-4

13. Bal GC, Panda MR, Panda SK, Mohanty BN. Pathology of parasitic infections in Deshi fowls. Indian J Vet Pathol. 2015:39(1):68-72.

14. Lalthanpuii PB, Zarzokimi, Lalchhandama K. Imperata cylindrica: a noxious weed of pharmacological potentials. In: Lalchhandama K, editor. Perspective and trends in the development of science education and research. Paris: Atlantis Press; 2018. p. 173-7.

15. MacDonald GE. Cogongrass (Imperata cylindrica)—biology, ecology, and management. Crit Rev Plant Sci. 2004:23(5):367-80.

16. Townson JK. Imperata cylindrica and its control. Weed Abstr. 1991; 40(11):457-68.

17. Yoon JS, Lee MK, Sung SH, Kim YC. Neuroprotective 2-(2-phenylethyl) chromones of Imperata cylindrica. J Nat Prod. 2006:69(2):290-1.

18. Matsunaga K, Shibuya M, Ohizumi Y. Graminone B, a novel lignan with vasodilative activity from Imperata cylindrica. J Nat Prod. 1994;57(12):1734-6.

19. Lalthanpuii PB, Zarzokimi, Lalchhandama K. Anthelmintic activity of praziquantel and Spilanthes acmella extract on an intestinal cestode parasite. Acta Pharm. 2020;2020(70):551-60.

20. Dey S, Baul TB, Roy B, Dey D. A new rapid method of air-drying for scanning electron microscopy using tetramethylsilane. J Microsc. 1989; 156(2):259-61.

21. Liu X, Zhang B, Chou G, Yang L, Wang Z. Chemical constituents from Imperata cylindrica. Zhongguo Zhong Yao Za Zhi. 2012;37(15):2296-300.

22. Liu RH, Chen SS, Gang RE, Feng SH, Huang HL. Phenolic compounds from roots of Imperata cylindrica var. major. Chin Herb Med. 2013;5(3):240-3.

23. Liu X, Zhang BF, Yang L, Chou GX, Wang ZT. Four new compounds from Imperata cylindrica. J Nat Med. 2014;68(2):295-301.

24. Cerdeira AL, Cantrell CL, Dayan FE, Byrd JD, Duke SO. Tabanone, a new phytotoxic constituent of cogongrass (Imperata cylindrica). Weed Sci. 2012; 60(2):212-8.

25. Xuan LI, Zhang BF, Li YA, Gui-Xin CH, Zheng-Tao WA. Two new chromones and a new flavone glycoside from Imperata cylindrica. J Nat Med. 2013;11(1):77-80.

26. Matsunaga K, Shibuya M, Ohizumi Y. Imperanene, a novel phenolic compound with platelet aggregation inhibitory activity from Imperata cylindrica. J Nat Prod. 1995;58(1):138-9.

27. Matsunaga K, Ikeda M, Shibuya M, Ohizumi Y. Cylindol A, a novel biphenyl ether with 5-lipoxygenase inhibitory activity, and a related compound from Imperata cylindrica. J Nat Prod. 1994;57(9):1290-3.

28. An HJ, Nugroho A, Song BM, Park HJ. Isoeugenin, a novel nitric oxide synthase inhibitor isolated from the rhizomes of Imperata cylindrica. Molecules. 2015;20(12):21336-45.

29. Köse YB, İşcan G, Demirci B, Bașer KH, Celik S. Antimicrobial activity of the essential oil of Centaurea aladagensis. Fitoterapia. 2007;78(3):253-4.

30. Saidana D, Mahjoub MA, Boussaada O, Chriaa J, Chéraif I, Daami M, et al. Chemical composition and antimicrobial activity of volatile compounds of Tamarix boveana (Tamaricaceae). Microbiol Res. 2008:163(4):445-55.

31. Harada H, Yamashita U, Kurihara H, Fukushi E, Kawabata J, Kamei Y. Antitumor activity of palmitic acid found as a selective cytotoxic substance in a marine red alga. Anticancer Res. 2002;22(5):2587-90.

32. Jeong JB, Jeong HJ. 2-Methoxy-4-vinylphenol can induce cell cycle arrest by blocking the hyper-phosphorylation of retinoblastoma protein in benzo [a] pyrene-treated NIH3T3 cells. Biochem Biophys Res Commun. 2010;400(1):752-7.

33. Jeong JB, Hong SC, Jeong HJ, Koo JS. Anti-inflammatory effect of 2methoxy-4-vinylphenol via the suppression of NF-KB and MAPK activation, and acetylation of histone H3. Arch Pharm Res. 2011;34(2011):2109-16.

34. Rangel-Sánchez G, Castro-Mercado E, García-Pineda E. Avocado roots treated with salicylic acid produce phenol-2, 4-bis (1, 1-dimethylethyl), a compound with antifungal activity. J Plant Physiol. 2014;171(2-3):189-98.

35. Huang YH, Mao ZC, Xie BY. Chinese leek (Allium tuberosum Rottler ex Sprengel) reduced disease symptom caused by root-knot nematode. J Integr Agric. 2016;15(2):364-72.
36. Choi JM, Lee EO, Lee HJ, Kim KH, Ahn KS, Shim BS, et al. Identification of campesterol from Chrysanthemum coronarium L. and its antiangiogenic activities. Phytother Res. 2007;21(10):954-9.

37. Awad AB, Downie A, Fink CS, Kim U. Dietary phytosterol inhibits the growth and metastasis of MDA-MB-231 human breast cancer cells grown in SCID mice. Anticancer Res. 2000;20(2):821-4.

38. De Stefani E, Boffetta P, Ronco AL, Brennan P, Deneo-Pellegrini H, Carzoglio JC, et al. Plant sterols and risk of stomach cancer: a case-control study in Uruguay. Nutr Cancer. 2000;37(2):140-4.

39. Schabath MB, Hernandez LM, Wu X, Pillow PC, Spitz MR. Dietary phytoestrogens and lung cancer risk. JAMA. 2005;294(12):1493-504.

40. Strom SS, Yamamura Y, Duphorne CM, Spitz MR, Babaian RJ, Pillow PC, et al. Phytoestrogen intake and prostate cancer: a case-control study using a new database. Nutr Cancer. 1999;33(1):20-5.

41. Gylling H, Plat J, Turley S, Ginsberg HN, Ellegård L, Jessup W, et al. Plant sterols and plant stanols in the management of dyslipidaemia and prevention of cardiovascular disease. Atherosclerosis. 2014;232(2):346-60.

42. Gabay O, Sanchez C, Salvat C, Chevy F, Breton M, Nourissat G, et al. Stigmasterol: a phytosterol with potential anti-osteoarthritic properties. Osteoarthritis Cartilage. 2010;18(1):106-16.

43. Panda S, Jafri M, Kar A, Meheta BK. Thyroid inhibitory, antiperoxidative and hypoglycemic effects of stigmasterol isolated from Butea monosperma. Fitoterapia. 2009;80(2):123-6.

44. Abongwa M, Martin RJ, Robertson AP. A brief review on the mode of action of antinematodal drugs. Acta Vet. 2017;67(2):137-52.

45. Clarke NE, Doi SA, Wangdi K, Chen Y, Clements AC, Nery SV. Efficacy of anthelminthic drugs and drug combinations against soil-transmitted helminths: a systematic review and network meta-analysis. Clin Infect Dis. 2018;68(1):96-105.

46. Taman A, Azab M. Present-day anthelmintics and perspectives on future new targets. Parasitol Res. 2014;113(2014):2425-33.

47. Greenberg RM. Ion channels and drug transporters as targets for anthelmintics. Curr Clin Microbiol Rep. 2014:1(2014):51-60.

48. Lalchhandama K. In vitro effects of albendazole on Raillietina echinobothrida, the cestode of chicken, Gallus domesticus. J Young Pharm. 2010;2(4):374-8.

49. Lalthanpuii PB, Zokimi Z, Lalchhandama K. Anthelmintic activity of praziquantel and Spilanthes acmella extract on an intestinal cestode parasite. Acta Pharma. 2020;70(4):551-60.

50. André WP, Cavalcante GS, Ribeiro WL, Santos JM, Macedo IT, Paula HC, et al. Anthelmintic effect of thymol and thymol acetate on sheep gastrointestinal nematodes and their toxicity in mice. Rev Bras Parasitol Vet. 2017;26(3):323-30.

51. Sant'Anna V, Railbolt M, Oliveira-Menezes A, Calogeropoulou T, Pinheiro J, de Souza W. Ultrastructural study of effects of alkylphospholipid analogs against nematodes. Exp Parasitol. 2018;187(2018):49-58.

\section{Publisher's Note}

Springer Nature remains neutral with regard to jurisdictional claims in published maps and institutional affiliations.
Ready to submit your research? Choose BMC and benefit from:

- fast, convenient online submission

- thorough peer review by experienced researchers in your field

- rapid publication on acceptance

- support for research data, including large and complex data types

- gold Open Access which fosters wider collaboration and increased citations

- maximum visibility for your research: over $100 \mathrm{M}$ website views per year

At BMC, research is always in progress.

Learn more biomedcentral.com/submissions 